\title{
Pengaruh Corporate Governance dan Ukuran Perusahaan Terhadap Kinerja Keuangan dan Firm Value dengan Sustainability Reporting sebagai Variabel Intervening
}

\author{
Rara Gustiana ${ }^{1}$, Wahyudin Nor ${ }^{2}$, Muhammad Hudaya ${ }^{3}$ \\ 1,2,3 Universitas Lambung Mangkurat, Banjarmasin, Indonesia
}

INFO ARTIKEL

JEL Classification :

G34, Q56

Keywords :

corporate governance, company value, sustainability reporting

\footnotetext{
ABSTRACT

*Email Korespondensi: raragustiana92@yahoo.com
}

This study aims to analyze more deeply the relationship of corporate governance and company size to financial performance and company value with sustainability reporting as an intervening variable. This study uses secondary data. The independent variables in this study are corporate governance and company size. The dependent variable in this study is financial performance and company value. The intervening variable used is sustainability reporting. GRI is used as a sustainability reporting alloy for index measurement bases. The sample of this study was 12 companies that published sustainability reporting and financial reports for three consecutive years in 2014-2016 which could be accessed through the company's website. Data analysis techniques in this study using Partial Least Square (PLS) with a calculation process that is assisted by a software application program. The results of the study show that there is no significant effect of corporate governance and company size on sustainability reporting. The results also indicate a positive and significant influence of corporate governance on financial performance, there is a significant effect of corporate governance on company value, and there is no significant influence of company size on financial performance and company values. Sustainability reporting does not mediate corporate governance and company size on financial performance and company value

\begin{abstract}
ABSTRAK
Penelitian ini bertujuan untuk menganalisis lebih dalam hubungan tata kelola perusahaan dan ukuran perusahaan dengan kinerja keuangan dan nilai perusahaan dengan pelaporan keberlanjutan sebagai variabel intervening. Penelitian ini menggunakan data sekunder. Variabel independen dalam penelitian ini adalah tata kelola perusahaan dan ukuran perusahaan. Variabel dependen dalam penelitian ini adalah kinerja keuangan dan nilai perusahaan. Variabel intervening yang digunakan adalah pelaporan keberlanjutan. GRI digunakan sebagai paduan pelaporan keberlanjutan untuk basis pengukuran indeks. Sampel penelitian ini adalah 12 perusahaan yang menerbitkan laporan keberlanjutan dan laporan keuangan selama tiga tahun berturut-turut pada 20142016 yang dapat diakses melalui situs web perusahaan. Teknik analisis data dalam penelitian ini menggunakan Partial Least
\end{abstract}




\section{Pendahuluan}

Tujuan utama perusahaan pada umumnya adalah menginginkan keuntungan sebesarbesarnya, sehingga pemilik modal menggunakan pelaporan akuntansi sebagai alat pertanggungjawaban (Gunawan dan Mayangsari, 2015). Laporan akuntansi digunakan sebagai alat pertanggungjawaban dikarenakan munculnya isu-isu mengenai pemanasan global, kerusakan alam, krisis sosial yang berdampak menjadi krisis ekonomi, eksploitasi sumber daya alam dan masyarakat dilakukan oleh perusahaan karena permintaan oleh pemilik modal (Gunawan dan Mayangsari, 2015).

Mengatasi hal tersebut perusahaan diharapkan untuk tidak hanya mementingkan kepentingan pemilik modal dan mananjemen, tetapi perusahaan juga memikirkan bagaimana dampak terhadap karyawan, konsumen, masyarakat dan juga lingkungan alam. Sebagai alat untuk mengatasi kekhawatiran masyarakat dan pemangku kepentingan lainnya maka perusahaan dapat menggunakan laporan keberlanjutan (Sustainability Reporting) (Gunawan dan Mayangsari, 2015). Pelaksanaan tanggungjawab sosial dan lingkungan berdasarkan kerangka pelaporan yang dikeluarkan oleh Global Reporting Index (GRI) yaitu sebuah pelaporan yang akuntabilitas dan transparansi (Gunawan dan Mayangsari, 2015).

Pelaporan SR masih bersifat voluntary, namun sudah $9 \%$ perusahaan yang terdaftar di BEI (Bursa Efek Indonesia) yang menerbitkan laporan SR, hampir sebagian besar menggunakan standar Global Index Reporting (GRI). Akhir tahun 2016, 49 perusahaan dan 12 Lembaga Jasa Keuangan (LJK) juga menerbitkan laporan keberlanjutan (OJK, terdiri atas 8 bank BUKU 3 dan 4 bank BUKU 4. Perusahaan yang non listing juga tidak kalah dalam menerbitkan laporan keberlanjutan. Antusiasme yang cukup tinggi ini merupakan laporan yang penting untuk diterbitkan terutama dalam hal untuk mengetahui bagaimana perusahaan mengintegrasikan aspek lingkungan, sosial dan tata kelola yang baik (OJK, 2017).

Perusahaan yang mengungkapkan Sustainability Reporting perlu didukung dengan tata kelola (corporate governance) pada perusahaan tersebut, karena melalui corporate governance perusahaan akan lebih berhati-hati dalam membuat laporan keberlanjutan dan laporan keuangan. Forum for Corporate Governance in Indonesia (2015) menjelaskan bahwa corporate governance (CG) adalah seperangkat peraturan yang mengatur tentang hubungan antara pemegang saham, pengurus (pengelola) perusahaan, kreditur, pemerintah, karyawan serta para pemangku kepentingan lainnya yang berhubungan dengan hak dan kewajiban diantara mereka. CG sendiri memiliki prinsipprinsip yaitu, transparansi, akuntabilitas, responsibilitas, independensi, kewajaran dan kesetaraan (KNKG, 2006).

Adapun tentang Penerapan Praktik corporate governance pada Badan Usaha Milik Negara (BUMN) Pasal 2 mewajibkan perusahaan BUMN untuk menerapkan CG termuat dalam Keputusan Menteri Negara Badan Usaha Milik Negara Nomor: KEP117/M-MBU/2002. Perusahaan yang menerapkan corporate governance dapat mengatasi konflik kepentingan, melalui teori keagenan menjelaskan mengenai masalah yang timbul ketika pemegang saham mengandalkan manajer untuk menyediakan 
jasa atas nama mereka (Jensen dan Meckling, 1976). Pihak manajemen (agent) dengan kewenangan yang dimilikinya dan bertindak hanya untuk kepentingan pribadi kemudian mengorbankan kepentingan pemegang saham, ini tidak sesuai dengan tujuan perusahaan yaitu menyejahterakan pemilik perusahaan (principal).

Menurut Gwenda dan Juniarti (2013) corporate governance adalah pengarahan dari sebuah mekanisme untuk mengawasi pelaksanaan corporate governance di sebuah organisasi. Mekanisme CG pada penelitian ini diproksikan oleh lima variabel mengacu dengan penelitian yang dilakukan oleh Black, et al (2003), yaitu shareholder rights board of directors, outside directors, audit committee and internal auditor dan disclousure to investors. Melalui mekanisme CG tersebut maka akan terlihat berapa score CG yang dimiliki perusahaan dan diharapkan dapat menjadi dasar bagi perusahaan konsisten dalam melakukan pengungkapan SR.

SR juga dapat dipengaruhi dari ukuran perusahaan, perusahaan yang berukuran besar dianggap dapat mengungkapkan sustainability reporting dengan konsisten karena ukuran perusahaan sendiri adalah suatu skala yang dapat diklasifikasikan dengan melihat dari total aktiva, $\log$ size, dan nilai pasar saham (Isbanah, 2015). Perusahaan yang berukuran perusahaan besar dapat menggunakan modal atau aktiva yang mereka miliki untuk melakukan pengungkapan sustainability reporting, karena pengungkapan sustainability reporting memerlukan biaya yang besar.

Meskipun biaya yang dikeluarkan perusahaan untuk melakukan pelaporan keberlanjutan cukup besar akan tetapi dengan melakukan pengungkapan SR dapat meningkatkan kinerja keuangan dan company value dilihat melalui harga saham perusahaan yang dapat memberikan efek sebagai alas an mengapa para investor akan menanamkan saham mereka pada perusahaan (Gunawan dan Mayangsari, 2015), untuk memperolah pencapaian kinerja keuangan dan company value yang besar perlu didukung dengan penerapan CG pada perusahaan.

Penerapan corporate governance dilaksanakan dengan mengikuti mekanisme corporate governance itu sendiri agar memberikan hasil sesuai dengan yang diharapkan. Menurut Fauzi, et al (2016) dengan mekanisme corporate governance ada yang mengawasi aktifitas manajer perusahaan untuk lebih efektif dalam meningkatkan kinerja keuangan. Kinerja keuangan yang meningkat akan membuat saham perusahaan juga meningkat, ini dapat menggambarkan bahwa penerapan corporate governance memberikan manfaat jangka panjang bagi perusahaan, yaitu adanya dampak keuangan secara langsung seperti peningkatan laba bersih dan akan menjadikan perusahaan yang sehat (Windah dan Fidelis, 2013).

Selain dilihat dari perusahaan yang sehat perusahaan juga dapat dilihat dari berapa banyak asset yang dimiliki perusahaan, karena asset yang dimiliki perusahaan dapat menjadi gambaran hak dan kewajiban permodalan sebuah perusahaan (MG dan Extallyus, 2013). Sehingga tata kelola dan ukuran perusahaan dapat memberikan dampak terhadap kinerja keuangan dan nilai perusahaan.

Penelitian yang dilakukan oleh Jouha (2015) menyatakan bahwa dampak dari tata kelola yang positif dilihat dari kepemilikan manajerial, kepemilikan institusional, dewan komisaris independen, komite audit atas laporan sustainability dan adanya dampak positif dari pelaporan berkelanjutan yang melaporkan kinerja keuangan dilihat dari sisi ROA, ada dampak positif dari governence perusahan terhadap kinerja entreprise dengan variabel intervening, yaitu sustainability reporting.

Menurut Sarafina dan Saifi (2017) hasil penelitiannya menunjukkan kinerja keuangan dan nilai perusahaan mempengaruhi dewan komisaris dan komite audit, hasil berbeda dengan penelitian yang dilakukan oleh Ferial, et al (2016), menunjukkan hasil bahwa CG tidak berpengaruh terhadap kinerja keuangan tetapi berpengaruh terhadap nilai perusahaan. Penelitian yang dilakukan Gunawan dan Mayangsari (2015), terkait pengaruh sustainability reporting menunjukkan bahwa SR tidak berpengaruh terhadap nilai perusahaan. Hasil penelitian Wijayanti (2015), menunjukkan bahwa sustainability reporting memiliki hasil yang signifikan terhadap kinerja keuangan.

Penelitian ini akan menguji kembali pengaruh corporate governance terhadap kinerja keuangan dengan variabel 
sustainability reporting sebagai variabel intervening. Penelitian ini merupakan pengembangan dari penelitian yang dilakukan oleh Jouha (2015), yang menguji pengaruh corporate governance on corporate financial and market performance with sustainabiity reporting as intervening variable.

Hasil penelitian terdahulu yang tidak konsisten, mendorong peneliti untuk menambahkan variabel dependen, yaitu company value karena company value merupakan indikator yang sangat penting bagi pasar. Company value merupakan nilai yang digunakan investor untuk pertimbangan investasi. Pada penelitian ini, nilai pasar diukur dengan menggunakan rasio $P B V$. Semakin tinggi rasio PBV maka semakin tinggi tingkat kemampuan memberikan keuntungan ekonomi (Siagian, et al 2013).

Kinerja Keuangan diukur menggunakan ROA (return on asset), ROA adalah sebuah gambaran kemampuan perusahaan atas keseluruhan dana yang ditanamkan untuk aktivitas dengan tujuan menghasilkan laba perusahaan melalui pemanfaatan aktiva yang dimiliki (Sarafina dan Saifi, 2017). Berdasarkan latar belakang di atas dan mengacu pada penelitian-penelitian terdahulu maka penelitian ini akan meneliti pengaruh corporate governance dan ukuran perusahaan terhadap kinerja keuangan dan company value: sustainibility reporting sebagai variabel intervening.

\section{Telaah Teori dan Pengembangan Hipotesis}

Teori yang melandasi corporate governance adalah agency theory adalah kontak atau hubungan antara principal dan agen. Keagenan merupakan hubungan sebuah kontrak yang terdiri dari satu orang atau lebih (prisipal) memerintah agen dengan tujuan untuk melaksanakan suatu jasa atas nama prinsipal yang diberikan wewenang dalam membuat keputusan (Jensen dan Meckling, 1976). Jika agen dan prinsipal memiliki tujuan yang sama dalam hal memaksimumkan company value (nilai perusahaan), maka dapat dipastikan agen akan bertindak dengan cara yang sesuai dengan kepentingan prinsipal.

Berdasarkan teori sustainability reporting (SR) merupakan sebuah laporan yang berisi informasi kinerja keuangan dan non keuangan yang terdiri dari aktivitas sosial dan lingkungan sehingga memungkinkan perusahaan bisa bertumbuh secara berkesinambungan (Gunawan dan Sekar, 2015). SR berkembang melalui konsep triple bottom line (TBL) atau yang lebih di kenal dengan 3P oleh filsup muda John Elkington pada tahun 1997 dalam bukunya "Cannibals with Forks, the Triple Bottom Line of Twentieth Century Bussiness" konsep triple bottom line degan istilah economic prosperity, environmental quality dan social justice, di mana pelaporan fokus awalnya hanya pada aspek keuangan, melainkan juga memperhatikan dari segi lingkungan dan aspek sosial (Wijayanti, 2015).

Corporate governance (CG) adalah sebuah dari sistem ekonomi pasar yang berkaitan erat dengan kepercayaan terhadap perusahaan yang melaksanakan (KNKG, 2006). Penerapan CG di Indonesia sangat penting pada perusahaan-perusahaan, karena diyakini dapat menunjang pertumbuhan dan stabilitas ekonomi yang berkesinambungan. Penerapan CG mendorong terciptanya persaingan yang sehat dan mendukung pemerintah dalam menegakkan CG di Indonesia. Setiap organisasi wajib menerapkan praktik CG mulai dari terbitnya pedoman umum CG oleh Komite Nasional Kebijakan Governance (KNKG). Menerapkan CG akan mengurangi konflik keagenan, dengan demikian pihak manajer dapat meningkatkan kemakmuran pemegang saham. Penerapan CG yang efektif dalam jangka panjang dapat meningkatkan kinerja badan usaha dan pemegang saham (Ferial et al, 2016). Prinsip-prinsip tentang dasar CG harus dipahami oleh setiap manajer dengan tujuan supaya perusahaan dapat dikelola dengan baik. Prinsip dasar CG yaitu transparansi, akuntabilitas, responsibilitas, independensi serta kewajaran dan kesetaraan (KNKG, 2006).

Ukuran perusahaan merupakan sebuah gambaran berapa besar aset yang dimiliki oleh perusahaan (Pantow et.al, 2015). Besar kecil sebuah perusahaan dapat mempengaruhi kemampuan perusahaan dalam menghadapi risiko-risiko yang mungkin akan ada dari berbagai situasi (Prastyorini, 2013).Penelitian ini mrnggunakan total aset sebagai penilaian ukuran perusahaan. Ukuran perusahaan yang 
semakin besar maka semakin luas dan detail informasi yang akan di berikan perusahaan, agar investor percaya dan melakukan investasi pada perusahaan tersebut (Hastuti, 2014).

Menurut Mualifin dan Priyadi (2016) kinerja keuangan biasanya diukur menggunakan rasio dimana rasio ini dapat dilihat pada periode tertentu menyangkut aspek penghimpunan dana ataupun penyaluran dana dapat dikatakan kinerja keuangan merupakan sebuah gambaran kondisi keuangan perusahaan. Kinerja keuangan dikelola oleh pihak manajemen yang menghasilkan informasi mengenai kondisi keuangan perusahaan. Investor sebagai pihak eksternal perusahaan akan tertarik dengan pengungkapan informasi kinerja keuangan, terutama informasi yang mengenai pendapatan saat ini dan pendapatan yang ada di masa mendatang. Pendapatan yang dihasilkan perusahaan tercermin dalam rasio ROA (return on asset) (Pratiwi dan Sumaryati, 2014). Menurut Puspitasari dan Endang (2010) ROA diperoleh melalui perbandingan antara net profit terhadap total assets perusahaan setelah disesuaikan dengan biaya-biaya untuk mendanai aset tersebut.

Company value (nilai perusahaan) adalah sebuah proksi yang mencerminkan kemakmuran para pemegang saham. Pemegang saham dapat melihat nilai perusahaan melalui rasio keuangan seperti PBV, menurut Siagian, et al (2013) PBV adalah rasio yang mengukur nilai yang diberikan pasar keuangan kepada manajemen dan organisasi perusahaan sebagai sebuah perusahaan yang terus tumbuh, dengan membandingkan harga saham dan nilai buku. PBV memberikan gambaran seberapa besar pasar menghargai nilai buku saham suatu perusahaan. Semakin tinggi rasio PBV, menunjukkan bahwa pasar semakin percaya akan prospek perusahaan tersebut.

Berdasarkan teori dan inkonsistensi hasil penelitian sebelumnya, maka hipotesis dalam penelitian ini dapat dirumuskan sebagai berikut:

H1: Corporate governance berpengaruh terhadap sustainability reporting

H2: Ukuran perusahaan berpengaruh terhadap sustainability reporting

H3: Sustainability reporting berpengaruh terhadap kinerja keuangan
H4: Sustainability reporting berpengaruh terhadap company value

H5: Corporate governance berpengaruh terhadap kinerja keuangan

H6: Ukuran perusahaan berpengaruh terhadap kinerja keuangan

H7: Corporate governance berpengaruh terhadap company value

H8: Ukuran perusahaan berpengaruh terhadap company value

H9: Sustainability reporting memediasi pengaruh antara Corporate governance terhadap kinerja keuangan

H10. Sustainability reporting memediasi pengaruh antara ukuran perusahaan terhadap kinerja keuangan

H11: Sustainability reporting memediasi pengaruh antara corporate governance terhadap company value

H12: Sustainability reporting memediasi pengaruh antara ukuran perusahaan terhadap company value.

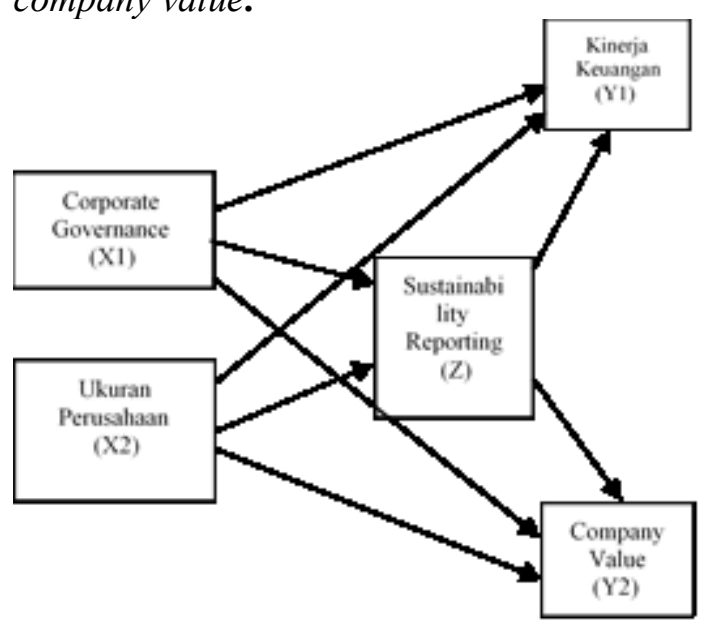

Gambar 1. Model Penelitian

\section{Metode Penelitian}

Populasi yang digunakan dalam penelitian ini adalah 20 perusahaan BUMN yang terdaftar di Bursa Efek Indonesia tahun 20142016. Metode purposive sampling digunakan dalam penelitian ini untuk menentukan sampel penelitian. Penarikan sampel di batasi dengan syarat-syarat sebagai berikut: (1) Perusahan BUMN yang terdaftar di BEI periode tahun 2014-2016. (2) Perusahan BUMN yang terdaftar di BEI yang menyajikan annual report dan sustainbility reporting dengan GRI G4 periode tahun 2014-2016. Penelitian ini menggunakan data- 
data yang diperoleh dari laporan keuangan tahunan dimana didalam laporan tahunan menyajikan informasi mengenai tata kelola perusahaan dan laporan keuangan perusahaan, kemudian data juga diperoleh dari laporan keberlanjutan perusahaan. Selanjutnya untuk memenuhi data sekunder diperoleh melalui situs Bursa Efek Indonesia dan dalam website masing-masing perusahaan.

Variabel independen pada penelitian ini ada dua variabel yaitu corporate governance dan ukuran perusahaan. Variabel indpenden pertama adalah Corporate Governance (CG). Menurut penelitian Gwenda dan Juniarti (2013) investor dapat menilai CG perusahaan tersebut baik atau tidaknya melalui score CG. CG sebagai variabel independen diproksikan menggunakan subindex (Black, et al 2003). Jika terpenuhi akan diberikan poin 1 dan apabila tidak terpenuhi akan diberikan poin 0 , untuk memperoleh score $\mathrm{CG}$ digunakan rumus (Clarista dan Devie, 2017):

$\mathrm{CGI}=\mathrm{A}+\{(\mathrm{B}+\mathrm{C}) / 2\}+\mathrm{D}+\mathrm{E}$

Variabel independen kedua dalam penelitian ini adalah ukuran perusahaan. Ukuran perusahaan merupakan gambaran total aset yang ada dalam sebuah perusahaan dan merupakan salah satu tolak ukur untuk menunjukkan besar kecilnya perusahaan. Penentuan ukuran perusahaan dalam penelitian ini menggunakan total asset (MG dan Extallyus, 2013).

$$
\text { Size: Ln (Total Asset) }
$$

Variabel dependen penelitian ini adalah kinerja keuangan dan company value. Variabel independen yang pertama adalah kinerja keuangan. Indikator kinerja keuangan yang digunakan dalam penelitian ini adalah ROA (return on assets). Membandingkan net profit terhadap total assets yang dimiliki perusahaan setelah disesuaikan dengan biayabiaya untuk mendanai aset maka akan dapat diketahui berapa ROA pada perusahaan (Puspitasari dan Endang, 2010). ROA dirumuskan dengan laba bersih setelah pajak dibagi total asset.

Variabel dependen kedua pada penelitian ini adalah Company value. Indikator yang digunakan untuk melihat nilai perusahaan adalah menggunakan PBV (Price to Book Value) mengacu dengan penelitian yang dilakukan oleh Siagian, et al (2013) yang diukur dengan membandingkan harga pasar per lembar saham yang digunakan adalah pada harga saham penutupan pada akhir tahun tertentu dengan nilai buku per lembar saham pada akhir tahun tertentu. Rumus rasio PBV, yaitu harga pasar per lembar saham dibagi dengan nilai buku per lembar saham.

\section{Keterangan:}

Variabel intervening pada penelitian ini adalah sustainability reporting dengan skala pengukuran rasio. Variabel ini diukur melalui perhitungan SRDI (Sustainability Report Disclosure Index) dengan memberikan nilai 1 jika item diungkapkan, dan 0 jika tidak diungkapkan. Kemudian memberikan skor pada seluruh item, skor tersebut selanjutnya dijumlahkan untuk memperoleh total skor pada setiap perusahaan. Formula untuk perhitungan SRDI adalah:

$\mathrm{SRDI}=\mathrm{V} / \mathrm{M}$

Keterangan:

SRDI = Sustainable Report Disclosure Index $\mathrm{V}=$ Jumlah item indikator yang diungkapkan $\mathrm{M}=$ Jumlah item indikator yang diharapkan

Penelitian ini menggunakan metode analisis path analysis (analisis jalur). Analisis jalur adalah penggunaan analisis regresi untuk menaksir hubungan kausalitas antar variabel yang telah ditetapkan sebelumnya, analisis jalur sendiri merupakan analisis regresi linier berganda dan dikembangkan (Ghozali, 2013).

Pendekatan Structural Equation Model (SEM) dengan menggunakan Sofware Partial Least Square (PLS) 3.0 digunakan untuk melakukan pengujian hipotesis pada penelitian. Analisis dengan menggunakan PLS terdapat 2 hal yang dilakukan, antara lain: (1) Model Pengukuran (Outer Mode)l. Konstruk berbentuk formatif, maka evaluasi model pengukuran dilakukan dengan melihat signifikansi weight-nya sehingga uji validitas dan reliabilitas konstruk tidak diperlukan (Ghozali, 2013). Memperoleh signifikansi weight harus melalui prosedur resampling (bootsrapping). Selain itu, menurut Ghozali (2013) menjelaskan bahwa uji multikolinearitas untuk konstruk formatif mutlak diperlukan dengan menghitung Tolerance. Nilai VIF yang direkomendasikan $<10$ atau $<5$ dan nilai Tolerance $>0,10$ atau $>$ 0,20. (2) Model Struktural (Inner Model). 
Menilai model struktural dengan PLS dimulai dengan melihat nilai $R$-Square untuk setiap variabel laten endogen sebagai kekuatan prediksi model structural (Ghozali, 2013). Perubahan nilai $R$-Square dapat digunakan untuk menjelaskan pengaruh variabel laten eksogen tertentu terhadap variabel laten endogen apakah mempunyai pengaruh yang substantif. Nilai $R$-Square 0,75: 0,50 dan 0,25 dapat disimpulkan bahwa model kuat, moderate dan lemah. Selain itu, menilai model struktural juga dilakukan dengan melihat signifikansi untuk mengetahui pengaruh antar variabel melalui prosedur bootsrapping (Ghozali, 2013). Pada penelitian ini, nilai signifikansi yang digunakan (two-tailed) tvalue adalah 1,96 (significance level $=5 \%$ ).

\section{Hasil Penelitian dan Pembahasan}

Analisis statistik deskriptif dalam penelitian mendeskripsikan tentang ringkasan data-data penelitian seperti nilai rata-rata (mean), nilai minimum, nilai maximum, standar deviasi dan sebagainya. Variabel independen pada penelitian ini adalah CG dan ukuran perusahaan, variabel dependen adalah kinerja keuangan dan company value. Kinerja keuangan pada penelitian ini diproksikan oleh ROA untuk variabel company value diproksikan oleh PBV kemudian untuk variabel Intervening pada penelitian ini adalah SR

Berikut ini merupakan gambaran umum masing-masing variabel yang digunakan dalam penelitian ini:

Tabel 1 Descriptive Statistic

\begin{tabular}{|c|c|c|c|c|c|}
\hline & $\mathrm{N}$ & Min & Max & Mean & Std. Deviation \\
\hline $\mathrm{CG}$ & 36 & 22.00 & 27.50 & 24.7222 & 1.31173 \\
\hline Ln_UP & 36 & 3.46 & 22.64 & 15.6475 & 5.28586 \\
\hline SR & 36 & .09 & .83 & .3603 & .16671 \\
\hline ROA & 36 & -.10 & .16 & .0523 & .05817 \\
\hline PBV & 36 & 2.00 & $\begin{array}{r}184000 \\
00.00\end{array}$ & 1028948.7778 & 3424483.96535 \\
\hline $\begin{array}{l}\text { Valid N } \\
\text { (listwise) }\end{array}$ & 36 & & & & \\
\hline
\end{tabular}

Sumber: Data hasil penelitian, diolah (2019)
Hasil pengujian Model Pengukuran (Outer Model)

Tabel 2 Laten Variable Correlations

\begin{tabular}{cccccc}
\hline \multicolumn{7}{c}{ CG } & Ln_UP & ROA & PBV & SR \\
\hline CG & 1,000 & & & & \\
\hline Ln_UP & 0.151 & 1,000 & & & \\
\hline ROA & 0.450 & -0.036 & 1,000 & & \\
\hline PBV & - & -0.000 & - & 1,000 & \\
& 0.180 & & 0.071 & & \\
\hline SR & 0.028 & 0.260 & - & - & 1,000 \\
& & & 0.069 & 0.078 & \\
\hline
\end{tabular}

Sumber: Output Smart PLS 3 (2019)

Hasil output statistik pada tabel 2 di atas menunjukkan bahwa besaran korelasi antar variabel independen tingkat korelasinya masih di bawah 95\%, maka dapat dikatakan tidak terjadi multikoleniaritas.

\section{Hasil Pengujian Model Struktural (Inner Model)}

Tabel 3 Nilai $R$-Square

\begin{tabular}{cc}
\hline & $\begin{array}{c}\text { R } \\
\text { Square }\end{array}$ \\
\hline ROA & 0.217 \\
\hline PBV & 0.040 \\
\hline SR & 0.068 \\
\hline
\end{tabular}

Sumber: Output Smart PLS 3 (2019)

Hasil output statistik pada tabel 3 di atas menunjukkan bahwa nilai pengaruh variabel corporate governance (CG), ukuran perusahaan dan SR terhadap Return On Assets (ROA) adalah sebesar 0,217 atau 21,7 \% dan sisanya $7,83 \%$ dipengaruhi oleh variabel lain di luar model penelitian ini. Nilai pengaruh variabel corporate governane (CG), ukuran perusahaan dan SR terhadap Price to Book Value (PBV) adalah sebesar 0,040 atau $4 \%$ dan sisanya $96 \%$ dipengaruhi oleh variabel lain di luar dari model penelitian ini. Nilai pengaruh variabel $C G$ dan ukuran perusahaan terhadap sustainability reporting (SR) adalah sebesar 0,068 atau $6,8 \%$ dan sisanya $93,2 \%$ dipengaruhi oleh variabel lain di luar dari model penelitian ini. 


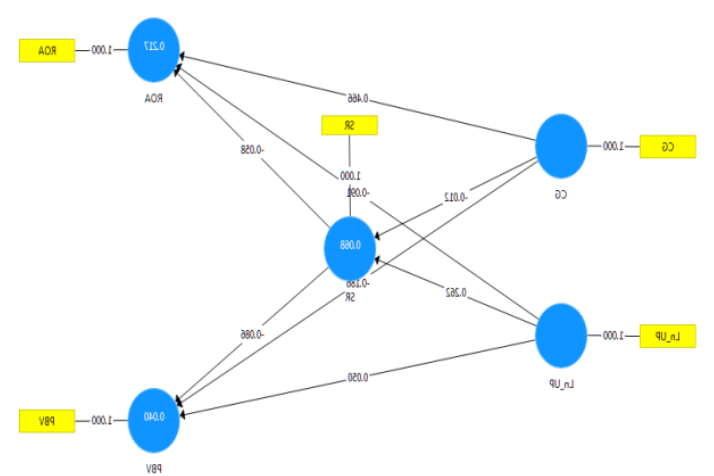

Sumber: Output Smart PLS 3 (2019)

Gambar 2 PLS Algorithma Pengaruh Langsung (Direct Effect) Corporate Governance terhadap Kinerja keuangan, Company Value dan Sustainability Reporting.

Berdasarkan gambar 2 di atas, menunjukkan bahwa koefisien direct effect CG terhadap kinerja keuangan sebesar 0,466. Koefisien direct effect CG terhadap company value yang diproksikan oleh PBV sebesar 0,186 . Koefisien direct effect $\mathrm{CG}$ terhadap sustainability reporting (SR) sebesar $-0,012$. Kemudian koefisien direct effect ukuran perusahaan terhadap kinerja keuangan sebesar $-0,091$. Koefisien direct effect ukuran perusahaan terhadap PBV sebesar 0,050. Selanjutnya koefisien direct effect SR terhadap kinerja keuangan sebesar $-0,058$ dan koefisien direct effect SR terhadap PBV sebesar $-0,086$.

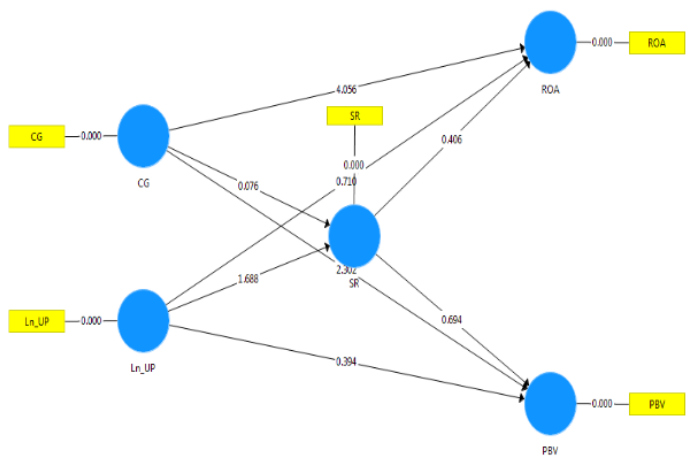

Sumber: Output Smart PLS 3.0 (2019)

Gambar 3 Bootstrapping Signifikansi Pengaruh Langsung (Direct Effect) Corporate Governance terhadap Kinerja keuangan, Company Value dan Sustainability Reporting.

\section{Hasil Pengujian Hipotesis dan Diskusi}

Tabel 4 Ringkasan uji hipotesis Pengaruh Langsung (uji T)

\begin{tabular}{|c|c|c|c|c|c|}
\hline & Sampel Asli (0) & Rata-rata Sam... & Standar Devias... & T Statistik (| 0/... & P Values \\
\hline$C G$ > PBV & -0.186 & -0.210 & 0.081 & 2.302 & 0.022 \\
\hline$C G$-> ROA & 0.466 & 0.461 & 0.115 & 4.056 & 0.000 \\
\hline$C G \rightarrow S R$ & -0.012 & -0.002 & 0.153 & 0.076 & 0.940 \\
\hline Ln_UP $\rightarrow$ PBV & 0.050 & 0.027 & 0.127 & 0.394 & 0.694 \\
\hline Ln_UP $\rightarrow$ ROA & -0.091 & -0.074 & 0.128 & 0.710 & 0.478 \\
\hline Ln_UP $\rightarrow$ SR & 0.262 & 0.261 & 0.155 & 1.688 & 0.092 \\
\hline SR $\rightarrow>$ PBV & -0.086 & -0.109 & 0.124 & 0.694 & 0.488 \\
\hline$S R \rightarrow R O A$ & -0.058 & -0.069 & 0.144 & 0.406 & 0.685 \\
\hline
\end{tabular}

Sumber: Output Smart PLS 3.0 (2019)

Tabel 5 Pengaruh tidak langsung (Intervening)

\begin{tabular}{|c|c|c|c|c|c|}
\hline \multicolumn{2}{|c|}{ Mean,STDEV, T-Values, P.Values } & Keyakinan Interval & \multicolumn{2}{|c|}{ Keyakinan Interval Bias-Dikoreksi } & Sampel \\
\hline & Sampel Asi (0) & Rata-rota Samm... & Standar Deviss... & $i k|0| \ldots$ & PValues \\
\hline$C G \rightarrow S R \rightarrow P B V$ & 0.001 & 0.002 & 0.029 & 0.035 & 0.972 \\
\hline $\operatorname{Ln} U P \rightarrow S R \rightarrow P P B V$ & .0 .023 & .0 .027 & 0.044 & 0.507 & 0.612 \\
\hline$C G \cdot S R \cdot \gg R O A$ & 0,001 & $\cdot 0,001$ & 0.024 & 0.029 & 0.977 \\
\hline $\operatorname{Ln}(U P \rightarrow S R \cdot \rightarrow R O A$ & $-0,015$ & -0.019 & 0.049 & 0,315 & 0.753 \\
\hline
\end{tabular}

Sumber: Output Smart PLS 3.0 (2019)

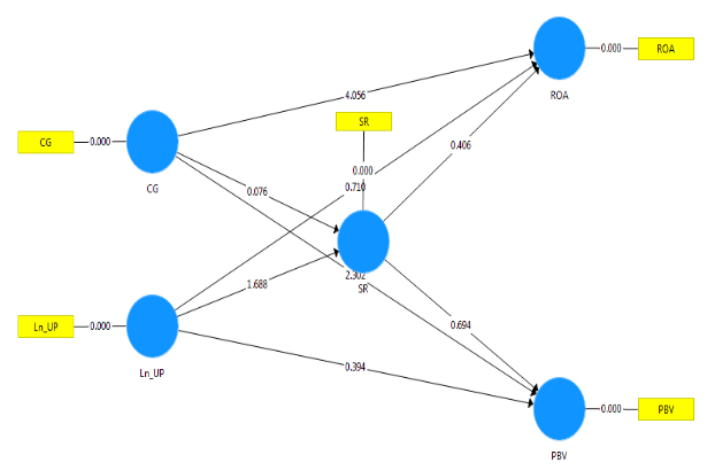

H1 menyatakan corporate governance (CG) berpengaruh terhadap sustainability reporting (SR). Berdasarkan tabel 4 di atas, menunjukkan bahwa $p$-values atau nilai signifikansi sebesar $0,940>0,05$. Artinya, variabel $C G$ tidak berpengaruh terhadap SR. Menunjukkan bahwa penerapan CG tidak mendorong perusahaan untuk melakukan pengungkapan sustainability reporting. Hasil dari penelitian ini berbeda dengan hasil penelitian yang dilakukan oleh Suryono dan Andri (2011), mereka menemukan bahwa CG berpengaruh terhadap SR. Pengungkapan SR yang bersifat voluntary menunjukkan bahwa perusahaan yang mengungkapkan SR secara sukarela menerbitkan laporan keberlanjutan 
karena belum ada aturan yang mewajibkan (Nasir et al ,2014).

H2 menyatakan ukuran perusahaan berpengaruh terhadap sustainability reporting (SR). Berdasarkan tabel 4 di atas, menunjukkan bahwa p-values atau nilai signifikansi sebesar 0,092<0,05. Artinya, variabel ukuran perusahaan tidak berpengaruh terhadap SR. Hal ini menunjukkan perusahaan yang memiliki ukuran perusahaan yang besar tidak mendorong perusahaan membuat laporan keberlanjutan. Hasil penelitian ini berbeda dengan hasil penelitian yanh dilakukan oleh Purwanto (2011) yang menunjukkan bahwa ungkapan pertanggung jawaban sosial dipengaruhi oleh ukuran perusahaan. Perusahaan besar memiliki inisiatif yang besar juga dalam melakukan dan mengungkapkan tanggungjawab sosial (Purwanto, 2011). Secara teoritis tekanan akan selalu ada pada perusahaan besar dan memiliki aktivitas operasi yang memiliki pengaruh yang lebih besar juga terhadap masyarakat, apabila pemegang saham ikut serta dalam memperhatikan kegiatan sosial yang dijalankan perusahaan makan tanggungjawab sosial perusahaan akan semakin luas(Purwanto, 2011).

H3 menyatakan sustainability reporting (SR) berpengaruh terhadap kinerja keuangan diukur melalui ROA. Berdasarkan pada tabel $4 \mathrm{di}$ atas, menunjukkan bahwa $p$-values atau nilai signifikansi sebesar $0,685>0,05$. Artinya, variabel SR tidak berpengaruh terhadap kinerja keuangan. Menunjukkan perusahaan yang melakukan pengungkapan SR tidak berdampak pada peningkatan kinerja keuangan pada perusahaan. Penelitian Wijayanti (2015), menyatakan bahwa pengungkapan SR yang luas akan meningkatkan ROA. Hutagalung dan Harahap (2016), menyatakan bahwa tidak terdapat pengaruh laporan keberlanjutan dari aspek ekonomi, sosial dan lingkungan dimana investor melakukan penilaian lain dalam menanamkan sahamnya, kondisi ini terjadi karena pengungkapan SR dalam jangka waktu yang pendek tidak akan memberikan dampak.

H4 menyatakan sustainability reporting berpengaruh terhadap company value Berdasarkan pada tabel 4 di atas, menunjukkan bahwa p-values atau nilai signifikansi sebesar $0,488>0,05$. Artinya, variabel SR tidak berpengaruh terhadap company value. Melihat dari hasil penelitian ini menunjukkan bahwa semakin bagus laporan SR perusahaan tidak mendorong meningkatnya nilai perusahaan dimata investor. Hasil penelitian Habibi dan Andraeny (2018), menemukan bahwa SR tidak berpengaruh terhadap nilai perusahaan. SR bertujuan untuk memberikan infornmasi keuangan dan non keuangan secara transparan kepada investor dan untuk menarik minat konsumen sehingga dapat meningkatkan nilai perusahaan (Habibi dan Andraeny, 2018). Hubungan yang baik antara agen dan prinsipal diharapkan dapat membuat sebuah hasil yang memuaskan bagi semua pihak. Melalui pengungkapan SR yang dilakukan oleh para agen diharapkan mampu dalam nilai perusahan melalui harga saham perusahaan, hal ini akan membuat kedua pihak mendapatkan keuntungan. Sehingga perusahaan BUMN diharapkan tetap stabil untuk keberlangsungan masyarakat.

H5 menyatakan CG berpengaruh terhadap kinerja keuangan perusahaan BUMN. Berdasarkan pada tabel 4 di atas, menunjukkan bahwa p-values atau nilai signifikansi sebesar $0,000<0,05$. Artinya, variabel $C G$ berpengaruh positif signifikan terhadap kinerja keuangan perusahaan BUMN. Hasil penelitian ini menunjukkan bahwa penerapan CG dapat meningkatkan kinerja keuangan pada perusahaan BUMN. Hasil penelitian ini mendukung penelitian yang dilakukan oleh Sarafina dan Saifi (2017) yang menemukan bahwa CG berpengaruh terhadap kinerja keuangan perusahaan. Hasil Penelitian yang dilakukan oleh Jouha (2015) menemukan bahwa kinerja keuangan dipengaruhi oleh tata kelola perusahaan. Agency Theory menjelaskan bahwa pemilik perusahaan menyerahkan pengelolaan perusahaan kepada tenaga-tenaga profesional untuk menjalankan bisnis perusahaan (Ferial et al ,2016).

H6 menyatakan ukuran perusahaan berpengaruh terhadap kinerja keuangan perusahaan BUMN. Berdasarkan tabel 4 di atas, menunjukkan bahwa $p$-values atau nilai 
signifikansi sebesar $0,485<0,05$. Artinya, variabel ukuran perusahaan tidak berpengaruh terhadap kinerja keuangan yang diukur melalui ROA. Hal ini menunjukkan bahwa ukuran perusahaan tidak dapat meningkatkan kinerja keuangan. Ukuran perusahaan akan meningkat apabila dilakukan dengan pengelolaan yang baik oleh para agen, dimana agen melakukan tugas untuk kepentingan prinsipal (MG dan Extallyus, 2013). Hasil penelitian ini sesuai dengan hasil yang dilakukan oleh MG dan Extallyus (2013) yang menyatakan bahwa ukuran perusahaan tidak mempengaruhi kinerja keuangan. Ukuran perusahaan yang semakin besar maka semakin rendah kinerja keuangannya, hal ini disebabkan karena perusahaan yang memiliki ukuran besar masih belum didukung dengan pengelolaan yang baik (Isbanah, 2015).

H7 menyatakan corporate governance (CG) berpengaruh terhadap company value. Berdasarkan pada tabel 4 di atas, menunjukkan bahwa $p$-values atau nilai signifikansi sebesar $0,022<0,05$. Artinya, variabel $\mathrm{CG}$ berpengaruh terhadap company value. Hal ini menunjukkan bahwa penerapan CG meningkatkan nilai perusahaan (company value) dimata investor. Hasil penelitian ini mendukung penelitian yang dilakukan oleh (Dinah \& Darsono, 2017) yang menyatakan CG berpengaruh terhadap nilai perusahaan. Sebagian besar perusahaan yang ada di Indonesia menerapkan CG hanya untuk memenuhi regulasi yang ada, sehingga masih sedikit perusahaan yang menerapkan CG sebagai budaya dalam perusahaan (Ramadhani et al ,2015), maka peneliti menduga informasi tentang CG tidak menjadi pertimbangan investor dalam mengambil keputusan untuk menanamkan saham disebuah perusahaan.

H8 menyatakan ukuran perusahaan berpengaruh terhadap company value perusahaan BUMN. Berdasarkan tabel 4 di atas, menunjukkan bahwa $p$-values atau nilai signifikansi sebesar $0,694<0,05$. Artinya, tidak ada pengaruh variabel ukuran perusahaan terhadap company value, dari hasil penelitian ini menunjukkan bahwa nilai perusahaan tidak dipengarhi oleh ukuran perusahaan. Menurut Dewi dan Wirajaya (2013) ukuran perusahaan mampu meningkatkan nilai perusahaan, karena semakin besar skala perusahaan maka akan semakin mudah bagi perusahaan dalam memperoleh sumber pendanaan baik dari internal maupun eksternal. Penelitian ini sesuai dengan hasil penelitian yang dilakukan oleh Dewi dan Wirajaya (2013) yang menyatakan bahwa ukuran perusahaan tidak berpengaruh terhadap nilai perusahaan. Jumlah aset yang besar akan menurunkan nilai perusahaan dari sisi pemilik perusahaan, ada kemudahan yang dimiliki oleh manajemen dalam mengendalikan perusahaan dalam meningkatkan nilai perusahaan dari sisi manajemen (Dewi Wirajaya, 2013).

H9 menyatakan pengaruh corporate governance terhadap kinerja keuangan dengan sustainability reporting sebagai variabel intervening. Berdasarkan tabel $5 p$-values atau nilai signifikansi sebesar $0,977>0,05$, maka dapat disimpulkan bahwa sustainability reporting tidak memediasi hubungan antara corporate governance terhadap kinerja keuangan. Hasil penelitian ini berbeda dengan hasil penelitian yang dilakukan oleh Jouha (2015) dimana SR memediasi pengaruh CG terhadap kinerja keuangan. Menurut Jouha (2015), laporan keberlanjutan memberikan pengaruh terhadap CG dalam meningkatkan kinerja keuangan perusahaan, hal ini karena melalui pengungkapan SR perusahaan dapat memberikan informasi mengenai aspek ekonomi, sosial dan lingkungan.

H10 menyatakan pengaruh ukuran perusahaan terhadap kinerja keuangan dengan sustainability reporting sebagai variabel intervening. Berdasarkan tabel $5 p$-values atau nilai signifikansi sebesar $0,0774>0,05$, maka dapat disimpulkan bahwa sustainability reporting tidak memediasi hubungan ukuran perusahaan terhadap kinerja keuangan. Hasil penelitian yang dilakukan oleh MG dan Extallyus (2013) ukuran perusahaan berpengaruh positif tidak signifikan terhadap kinerja keuangan. Hal ini disebabkan 
perusahaan memiliki kekuatan finansial yang lebih besar dalam menunjang kinerja tetapi disisi lain, perusahaan dihadapkan pada masalah keagenan yang lebih besar. Perusahaan dengan aset besar biasanya akan mendapatkan perhatian lebih dari masyarakat, perusahaan yang memiliki aset yang besar diimbangi dengan biaya yang besar, sehingga ukuran perusahaan tidak berpengaruh secara optimal terhadap kinerja keuangan. Pengungkapan SR yang berbeda setiap perusahaan membuat nilai masing-masing perusahaan untuk skor SR juga berbeda-beda, tergantung keperluan perusahaan. Selain itu SR juga masih bersifat sukarela membuat beberapa perusahaan tidak konsisten mempublikasikan SR. Sehingga SR tidak dapat mendorong perusahaan untuk meningkatkan kinerja keuangan.

H11 menyatakan pengaruh corporate governance terhadap company value dengan sustainability reporting sebagai variabel intervening. Berdasarkan tabel $5 p$-values atau nilai signifikansi sebesar $0,972>0,05$, maka dapat disimpulkan bahwa sustainability reporting tidak memediasi hubungan antara corporate governance terhadap nilai perusahaan. Menurut Gunawan dan Mayangsari (2015) SR tidak memiliki pengaruh terhadap nilai perusahaan. Sebuah perusahaan yang memperhatikan aspek ekonomi, sosial dan lingkungan akan menjamin nilai perusahaan (Habibi dan Andraeny, 2018). Hal tersebut ada karena tuntutan masyarakat luas tentang bagaimana sebuah perusahaan dapat berperan dalam masyarakat (Pratiwi dan Sumaryati, 2014).

Masyarakat semakin lama semakin kritis dalam hal memperhatikan praktik bisnis global, hal ini dikarenakan terjadinya tragedi lingkungan dan kemanusiaan diberbagai belahan dunia (Pratiwi dan Sumaryati, 2014). Peristiwa seperti ini memerlukan peranan penting dari pihak manajemen untuk melakukan pengungkapan SR dengan konsisten melalui penerapan $\mathrm{CG}$ dengan prinsip-prinsip nya yaitu, transparansi, akuntabilitas, responsibilitas, independensi, kewajaraan dan kesetaraan (KNKG, 2006).
H12 menyatakan pengaruh ukuran perusahaan terhadap company value dengan sustainability reporting sebagai variabel intervening. Berdasarkan tabel $6 p$-values atau nilai signifikansi sebesar $0,0645>0,05$, maka dapat disimpulkan bahwa sustainability reporting tidak memediasi hubungan antara ukuran perusahaan terhadap nilai perusahaan. Hasil penelitian yang dilakukan oleh Prastyorini (2013) menyatakan bahwa ukuran perusahaan berpengaruh terhadap nilai perusahaan. Perusahaan besar memiliki risiko yang lebih rendah daripada perusahaan kecil. Hal ini dikarenakan perusahaan besar memiliki kontrol yang lebih baik terhadap kondisi pasar, sehingga mereka mampu menghadapi persaingan ekonomi. Selain itu perusahaan-perusahaan besar mempunyai lebih banyak sumberdaya untuk meningkatkan nilai perusahaan karena memiliki akses yang lebih baik terhadap sumber-sumber informasi eksternal dibandingkan dengan perusahaan kecil (Prastyorini, Pengaruh Ukuran Perusahaan, Leverage, Price Earning Ratio dan Profitabilitas terhadap Nilai perusahaan, 2013).Besarnya ukuran perusahaan juga akan berdampak pada keputusan manajemen untuk mengambil kebijakan pembiayaan apa yang nantinya akan bermanfaat bagi perusahaan, supaya keputusan pembiayaan mampu mengoptimalkan nilai perusahaan (Fauzi, 2018).

\section{Kesimpulan, Keterbatasan dan Implikasi Hasil Penelitian}

Berdasarkan hasil pengujian dari beberapa hipotesis pada penelitian ini maka dapat disimpulkan bahwa, ada dua hipotesis yang hasilnya berpengaruh, yaitu corporate governance berpengaruh terhadap kinerja keuangan. Artinya, penerapan corporate governance dapat meningkatkan kinerja keuangan perusahaan dan corporate governance berpengaruh terhadap company value. Artinya, tata kelola yang dilakukan perusahaan mendorong meningkatnya nilai perusahaan. Selanjutnya dari hasil pengujian ada sepuluh hipotesis yang tidak berpengaruh yaitu, corporate governance terhadap sustainability reporting; ukuran perusahaan terhadap kinerja keuangan, company value 
dan sustainability reporting; sustainability reporting terhadap kinerja keuangan dan company value sustainability reporting sebagai variabel intervening.

Keterbatasan penelitian ini adalah tidak adanya konsistensi perusahaan dalam menerbitkan sustainability reporting setiap tahunnya, sehingga data penelitian tidak lengkap untuk melakukan analisis. Hal ini terjadi karena tidak ada peraturan di dalam undang-undang BUMN yang mengatur batas pelaporan sustainability reporting, sehingga perusahaan dapat kapan saja melaporkan sustainability reporting.

Hasil penelitian ini menunjukkan bahwa ada pengaruh dari variabel independen yaitu corporate governance ke dependen yaitu kinerja keuangan dan company value pada perusahaan BUMN di Indonesia, hal ini sesuai dengan pernyataan yang diungkapkan dalam theory agency (teori keagenan) yang menyatakan bahwa dengan tidak adanya konflik keagenan dalam perusahaan antara agen dan prinsipal, akan mempermudah perusahaan dalam menerapkan tata kelola perusahaan. Sehingga dengan menerapkan tata kelola yang baik dapat membuat kinerja keuangan perusahaan tersebut meningkat melalui pengelolaan aset perusahaan yang dilakukan oleh agen yang bertanggungjawab mengelola perusahaan dan membuat nilai perusahaan eningkat. Hal ini menunjukkan bahwa variabel tersebut perlu diperhatikan para investor dalam pengambilan keputusan untuk menanamkan saham mereka pada perusahaan BUMN. Melalui konsep teori yang menjadi dasar penelitian ini bahwa CG yang baik dapat mengurangi adanya konflik keagenan dalam perusahaan sehingga berdampak positif pada kinerja keungan yang ada pada perusahaan. Bagi peneliti selanjutnya dapat melakukan penelitian lebih dalam dengan menambah akuntansi lingkungan dan CSR.

\section{Daftar Pustaka}

Achyani, F., Triyono, \& Wahyono. (2015). Pengaruh Praktik Corporate Governance
Terhadap Nilai Perusahaan dengan Manajemen Laba Sebagai Variabel Intervening (Studi Kasus Pada Perusahaan Publik di Indonesia). Univesty Research Colloquium, 171-187.

Agus, S. (2017). Pengaruh Good Corporate Governance Terhadap Nilai Perusahaan dengan Kinerja Keuanagan Sebagai Variabel Intervening. Ekonomi dan Bisnis, 67-77.

Black, B. S., Jang, H., \& Kim, W. (2003). Does Corporate Governance Affect Firm Value? Evidance From Korea. Journal of law Economics and Organization, 1-74.

Brooks, L. J., \& Paul, D. (2014). Business dan Professional Ethics. Jakarta: Salemba Empat.

Clarista, F. V., \& Devie. (2017). Pengaruh Corporate Governance Terhadap Firm Value dengan Earning Quality Sebagai Variabel Intervening Pada Perusahaan yang Terdaftar di LQ45. Business Accounting Review. Vol. 5 No. 1, 265-276.

Darwis, H. (2012). Manajemen Laba Terhadap Nilai Perusahaan dengan Corporate Governance sebagai pemoderasi. Jurnal Keuangan dan Perbankan, Vol 16 No. 1, 45-55.

Dewi, A. S., \& Wirajaya, A. (2013). Pengaruh Struktural Modal, Profitabilitas dan Ukuran Perusahaan pada nilai perusahaan. E-Jurnal Akuntansi Universitas Udayana, 358-372.

Dinah, A. F., \& Darsono. (2017). Pengaruh Tata Kelola Perusahaan, Profitabilitas dan Penghindaran Pajak Terhadap Nilai Perusahaan. Diponegoro Journal of Accounting, 1-15.

Fatchan, I. N., \& Trisnawati, R. (2016). Pengaruh Good Corporate Governance Pada Hubungan antara Sustainability Report dan Nilai Perusahaan. Riset Akuntansi dan Keuangan Indonesia, 25-34.

Fauzi, A. S., Suransi, N. K., \& Alamsyah. (2016). Pengaruh GCG dan CSR terhadap Nilai Perusahaan dengan Proftabilitas Sebagai Variabel Pemoderasi. Jurnal infestasi, 1-19. 
Fauzi, M. S. (2018). Pengaruh Struktural Modal, Ukuran Perusahaan dan Profitabilitas terhadap Nilai Perusahaan Sektor Agriculture Tahun 2012-2015. Jurnal Ilmu Manajemen, 1-8.

Ferdiana, N. (2012). Pengaruh Corporate Governance Terhadap Kinerja Keuangan Perusahaan Pertambangan di BEI. Jurnal Ilmiah Mahasiawa Akuntansi, 11-15.

Ferial, F., Suhandak, \& Handayani, S. R. (2016). Pengaruh Good Corporate Governance terhadap Kinerja Keuangan dan Dampaknya pada Nilai Perusahaan (Studi Kasus pada Badan Usaha Milk Negara yang terdaftar di Bursa Efek Indonesia periode 2012-2014). Jurnal Administrasi Bisnis, 146-153.

Forum For Corporate Governance In Indonesia. (2015, September).

Ghozali, I. (2013). Aplikasi Analisis Multivariate dengan program IBM SPSS 21 . Semarang: Universitas Diponegoro. . (2016). Desain Penelitian Kuantitatif dan Kualitatif. Semarang: Yoga Pratama.

GRI. (2016, 12 23). Global Reporting Initiative.

Gunawan, Y., \& Sekar, M. (2015). Pengaruh Sustainability Reporting Terhadap Nilai Perusahaan dengan Investment Opportunity Set Sebagai Variabel Moderating. e-Journal Akuntansi Trisakti Volume. 2 Nomor. 1, 1-12.

Gwenda, Z., \& Juniarti. (2013). Pengaruh Penerapan Good Corporate Governance (GCG) Pada Variabel Share Ownership, Debt Ratio dan Sektor Industri Terhadap Nilai Perusahaan. Business Accounting Review, 137-149.

Habibi, M., \& Andraeny, D. (2018). Pengaruh Profitabilitas dan Sustainability Reporting terhadap Nilai Perusahaan dengan Investment Opportunity Set Sebagai Variabel Moderating. Akuntansi, 1-8.

Hasanah, N., Syam, D., \& Jati, W. A. (2015). Pengaruh Corporate Governance terhadap Pengungkapan Sustainability Reporting pada Perusahaan di Indonesia. Jurnal Reviu Akuntansi dan Keuangan, 711-720.
Hastuti, W. (2014). Pengaruh Ukuran Perusahaan, Pertumbuhan Perusahaan dan Tipe Industri terhadap Pengungkapan Tanggung Jawab Sosial Perusahaan dalam Laporan Tahunan. Fakultas Ekonomi Universitas Negeri Padang, 1-25.

Hutagalung, A., \& Harahap, K. (2016). Pengaruh Pengungkapan Sustainability Report terhadap Profitabilitas Perusahaan Manufaktur yang terdaftar di Bursa Efek Indonesia Periode 2009-2012. Jurnal Akuntansi, keuangan dan perpajakan Indonesia, 1-14.

IAI. (2015, Juni). ED Amandemen PSAK 1. Jakarta, DKI Jakarta, Indonesia.

Ionescu, L. (2012). Effects of Corporate Governance on Firm Value . Economics, management, and financial market, 215220.

Isbanah, Y. (2015). Pengaruh ESOP, Leverage, and Ukuran Perusahaan tethadap Kinerja Keuangan Perusahaan di Bursa Efek Indonesia. Journal of Research in Economics and Management, 28-41.

Jensen, M. C., \& Meckling, W. (1976). Theory of the firm: managerial Behaviour, Agency Cost and Ownership Structure. Journal of Financial Economics , 305-360.

Jouha, F. (2015). Effect of Corporate Governance on Corporate Financial and Market Performance with Sustanibility Reporting as Intervening Variable. South East Asia Journal of Contemporary Business, Economics and Law, Vol. 6, Issue 1 (Apr.), 1-6.

Jusmarni. (2016). Pengaruh Sustainability Reporting Terhadap Kinerja Keuangan dari sisi Market Value Ratios dan Asset Management Ratios. Jurnal SOROT Volume 11, Nomor 1, April 2016: 29 - 45.

K, P., V, R., \& M, R. (2017). Corporate Governance and Firms' Performance of Mauritian Listed Companies. International Journal of Financial Management and Reporting Analysis, 1-26.

Khafid, M., \& Mulyaningsih. (2012). Kontribusi Karakteristik Perusahaan dan Corporate Governance Terhadap Publikasi 
Sustainability Report. Jurnal Ekonomi dan Keuangan, 340-359.

KNKG. (2006). Pedoman Umum Good Corporate Governance Indonesia. Jakarta.

Kurnianingsih, H. T. (2013). Pengaruh Profitabilitas dan size Perusahaan terhadap Corporate Social Responsibility. Jurnal Riset Akuntansi dan Bisnis, 91-111.

Limanto, A. W., \& Juniarti. (2014). Pengaruh Penerapan Good Corporate Governance Terhadap Nilai Perusahaan yang Terdaftar di Bursa Efek Indonesia 2007-2011. Business Accounting Review, 21-30.

Maharani, S. N. (2014). Sustanibility Reporting Sebagai Media Perusahaan dalam Mengembangkan dan Melaporkan Kebijakan Bisnis Berkelanjutan. MODERNISASI, Volume 10, Nomor 1, Februari 2014, 11-22.

MG, I. K., \& Extallyus, L. (2013). Pengaruh Corporate Governance Prepection Index (CGPI), Struktur Kepemilikan dan Ukuran Perusahaan terhadap Kinerja Keuangan. Jurnal Bisnis dan Ekonomi, 171-183.

Mualifin, O. R., \& Priyadi, M. P. (2016). Dampak Pengungkapan Sustaiability Reporting Terhadap Kinerja Keuangan dan Kinerja Pasar. Jurnal Ilmu dan Riset Akuntansi.

Muliani, L. E., Yuniarta, A., \& Sinarwati, K. (2014). Pengarh Kinerja Keuangan terhadap Nilai Perusahaan dengan Pengungkapan Corporate Social Responsibility dan Good Corporate Governance sebagai Variabel Pemoderasi (Studi Kasus di Bursa Efek Indonesia periode 2010-2012. e-Journal SI Ak Universitas Pendidikan Ganesha Vol. 2 No. 1, 1-10.

Nasir, A., lham, E., \& Utara, V. I. (2014). Pengaruh Karakteristik Perusahaan dan Corporate Governance Terhadap Pengungkapan Sustainability Report Pada Perusahaan LQ45 yang Terdaftar. Jurnal Ekonomi.

Natalia, R., \& Tarigan, J. (2014). Pengaruh Sustainability Reporting terhadap Kinerja Keuangan Perusahaan Publik dari sisi
Profitability Ratio. Business Accounting Review, 111-121.

OJK. (2017, Maret). Infografis Lembaga Jasa Keuangan dan Emiten Penerbit Sustainability Report.

(2017, Agustus). Peraturan Otoritas Jasa Keuangan Nomor 51/POJK.03/2017 tentang Penerapan Keuangan Berkelanjutan bagi Lembaga Jasa Keuangan, Emiten dan Perusahaan Publik.

Pahlevi, M., Wilopo, \& Mawardi, M. K. (2016). Penerapan Prinsip Good Corporate Goverance (GCG) Pada BUMN Berorientasi Global (Stud Kasus pada PT Semen Indonesia (Persero) Tbk. dalam Mengelola Thang Long Cement Joint Stock Company). Jurnal Administrasi Bisnis, 86-95.

Pantow, M. S., Murni, S., \& Trang, I. (2015). Analisa Pertumbuhan Penjualaan, Ukuran Perusahaan, Return On Asset dan Stuktur Modal terhadap Nilai Perusahaan yang tercatat di Indeks LQ 45. Jurnal EMBA, 961-971.

Prastyorini, B. F. (2013). Pengaruh Ukuran Perusahaan, Leverage, Price Earning Ratio dan Profitabilitas terhadap Nilai perusahaan. Jurnal Ilmu Manajemen, 183196.

Pratiwi, R. D., \& Sumaryati, A. (2014). Dampak Sustainability Reporting Terhadap Kinerja Keuangan dan Risiko Perusahaan. Dinamika Akuntansi, 153-167. Retrieved from

Prayosho, I. S., \& Hananto, H. (2014). Pengaruh Sustanibility Reporting terhadap Abnormal Return Saham pada Badan Usaha Sektor Pertambangan yang terdaftar di BEI Periode 2010 -2012. Calyptra: Jurnal Ilmiah Mahasiswa Universitas Surabaya Vol 2 No 2 (2014).

Purwanto, A. (2011). Pengaruh Tipe Industri, Ukuran Perusahaan, Profitabilitas Terhadap Corporate Social Responsibility. Jurnal Akuntansi dan Auditing, 1-94.

Puspitasari, F., \& Endang, E. (2010). Pengaruh Mekanisme Corporate Governance Terhadap Kinerja Keuangan. Manajemen Teori dan Terapan, 189-215. 
Rachmania, D. (2017). Pengaruh corporate governancem corporate social Responsibility dan Komisaris Independen terhadap Nilai Perusahaan pada Industri Tekstil dan Garmen Periode 2011-2013. Competitive, 39-62.

Rahmawati, N., \& Amboningtyas, D. (2017). The Influence Profitability and Leverage to Company Values with Divident Policies as Intervening Variabel (In LQ 45 Company Listed in BEI Period 2012-2016). Ekonomika dan Bisnis.

Ramadhani, S., Andreas, \& Desmiyawati. (2015). Pengaruh Corporate Governanace Perception Index dan Kebijakan Hutang terhadap Nilai Peusahaan dengan Kebijakan Dividen sebagai Variabel Intervening. Jurnal Akuntansi, 1-14.

Retno, R. D., \& Prihatinah, D. (2012). Pengaruh Good Corporate Governance dan Pengungkapan Corporate Sosial Responsibility Terhadap Nilai Perusahaan. Jurnal Nominal, 84-103.

Robin, K. O. (2016). Pengaruh Tata Kelola Perusahaan Terhadap Nilai Perusahaan Pada Perusahaan Sektor Keuangan yang Terdaftar di BEI. Volume 20, Nomor 1, 122.

Safitri, D. A. (2015). Sustanibility Report Terhadap Kinerja Keuangan dan Pasar. Jurnal Ilmu \& Riset Akuntansi Vol. 4 No. 4.

Sarafina, S., \& Saifi, M. (2017). Pengaruh Good Corporate Governance Terhadap Kinerja Keuangan dan Nilai Perusahaan (Studi pada Badan Usaha Milik Negara (BUMN) yang terdaftar di Bursa Efek Indonesia Periode 2012-2015). Jurnal Administrasi Bisnis, 108-117.

Sarwono, J. (2007). Analisis Jalur untuk Riset Bisnis dengan SPSS. Yogyakarta: Penerbit ANDI.

Setyawan, K. M., \& Putri Dwija, I. A. (2013). Pengaruh Good Corporate Governance terhadap Kinerja Keuangan Lembaga Pengkreditan Desa di Kecamatan Mengwi Kabupaten Bandung. Jurnal Akutansi Universitas Udayana, 586-598.
Siagian, F., Siregar, S. V., \& Rahadian, Y. (2013). Corporate Governance, Reporting Quality and firm value: evidence from Indonesia. Jurnal of Accounting in Ernerging Economies.

Simbolon, J., \& Sueb, M. (2016). Pengaruh Pengungkapan Sustainability Report Terhadap Kinerja Keuangan Perusahaan. Simposium Nasional Akuntansi XIX. Lampung: IAI.

Sulistio, A., \& Saifi, M. (2017). Analisis Penentuan truktur Modal yang Optimal untuk Menigkatkan Nilai Perusahaan (Studi Kasus PT Astra Graphia Tbk Periode 2013-2015). Jurnal Administrasi Bisnis, 37-45.

Suryono, H., \& Andri, P. (2011). Pengaruh Karakteristik Perusahaan dan Corporate Governance Terhadap Praktik Pengungkapan Sustainability Report. Fakultas Ekonomi Universitas Syiah Kuala, 1-30.

Susanto, Y. K., \& Tarigan, J. (2013). Pengaruh Pengungkapan Sustainability Report terhadap Profitabilitas Perusahaan. BUSINESS ACCOUNTING REVIEW, VOL. 1, 2013.

Thaharah, N., \& Asyik, N. F. (2016). Pengaruh mekanisme Corporate Governance dan Kinerja Keuangan Terhadap Nla Perusahaan LQ45. Jurnal Ilmu dan Riset Akuntansi.

Tumewu, R. C. (2014). Pengaruh Penerapan Good Corporate Governance Terhadap Leverage dan Proofitabilitas pada Perusahaan Perbankan yang Terdaftar di BEI 2009-2013. Accountability, 1-10.

Veno, A. (2015). Pengaruh Corporate Governance Terhadap Kinerja Perusahaan Pada Perusahaan Manufaktur go Public (Studi Empiris Pada Perusahaan yang terdaftar di BEI 2011 sampai 2013). Benefit Jurnal Manajemen dan Bisnis Vol. 19 No. 1, 95-112.

Wijayanti, R. (2016). Pengaruh Pengungkapan Sustanibility Reporting Terhadap Kinerja Keuangan. Syariah Paper Accounting FEB UMS, 39-51. 
Rara Gustiana, Wahyudin Nor, Muhammad Hudaya: Pengaruh Corporate Governance dan Ukura Perusahaan Terhadap Kinerja Keuangan dan Firm Value dengan Sustainability Reporting ...

Windah, G. C., \& Fidelis, A. A. (2013). Pengaruh Penerapan Corporate Governance terhadap kinerja keuangan perusahaan hasil survei the Indonesian Institute Perception Governance (IICG) Periode 2008-2011. Jurnal Ilmiah Mahasiswa Universitas Surabaya, 1-20. 